\title{
Rádios comunitárias na Baixada Fluminense: comunicação local em movimento
}

\author{
Community Radio in the Baixada Fluminense: Local Communication on the Move
}

\author{
Sandra Sueli Garcia de Sousa ${ }^{1}$, Nathália de Souza Mendonça ${ }^{2}$
}

\begin{abstract}
Resumo: As rádios comunitárias foram regulamentadas no Brasil em 1998. Desde então, enfrentam muitos embates para continuarem funcionando: burocracia, falta de recursos, falta de participação do ouvinte, ausência de programas de capacitação etc. E, no entanto, se mantêm vivas e atuantes. Este artigo conceitua o que vem a ser a rádio comunitária a partir de López Vigil (2003) e mostra a atuação de duas emissoras comunitárias da Baixada Fluminense: Rádio Serra Verde FM, em Xerém, Duque de Caxias, e Rádio Mirandela FM, em Nilópolis. O objetivo é mostrar a importância dessas emissoras em uma comunicação propositiva e cidadã. Além disso, procuramos analisar como se dá a interação dos ouvintes junto às emissoras durante o programa Espaço Aberto da Rádio Serra Verde FM e a live A Vida É Muito Mais, transmitida pela página da Rádio Mirandela no Facebook. Para tanto, faz-se uso do conceito de contrato de comunicação de Patrick Charaudeau (2005; 2018). Comprova-se que as emissoras possuem forte apelo junto à comunidade inserida, pois representam um canal de comunicação pelo qual as pessoas acessam seus direitos, recorrem à resolução de problemas nos lugares em que se encontram e vivenciam as produções culturais das cidades da Baixada.
\end{abstract}

Palavras-chave: Rádio; Comunicação; Rádios comunitárias; Ouvintes; Cidadania.

Abstract: Community radio stations were regulated in Brazil in 1998. Since then, they have faced many struggles to keep working: bureaucracy, lack of resources, lack of participation by the listener, absence of training programs, etc. But they remain alive and active. This article conceptualizes community radio (López Vigil, 2003) and shows the performance of two community broadcasters from Baixada Fluminense: Rádio Serra Verde FM, in Xerém, Duque de Caxias, and Rádio Mirandela FM, in Nilópolis. The objective is to show the importance of these stations in a purposeful and citizen communication. In addition, we seek to analyze how listeners interact with broadcasters during the Radio Serra Verde FM Espaço Cidadão program and the A Vida É Muito Mais live broadcast on Rádio Mirandela's Facebook page. For this purpose, we used Patrick Charaudeau's concept of communication contract $(2005 ; 2018)$. It has been proved that broadcasters have a strong appeal to the community, as they represent a communication channel through which people may have access to their rights, solve local problems and experience the cultural productions in the cities of Baixada.

Keywords: Radio stations; Communication; Community radio stations; Listeners; Citizenship.

\footnotetext{
${ }^{1}$ Jornalista pela Universidade Federal do Pará (UFPA); Mestre em Teoria e Ensino da Comunicação pela Universidade Metodista de São Paulo (UMESP); Doutora em Comunicação e Semiótica pela PUC-SP. Professora adjunta no curso de Jornalismo da Universidade Rural do Rio de Janeiro (UFRRJ).

${ }^{2}$ Graduanda do curso de Jornalismo na UFRRJ. Bolsista Pibic, CNPq.
} 


\section{Introdução}

As rádios comunitárias brasileiras funcionam de forma regulamentada há mais de 20 anos por meio da lei $n^{\circ} 9.612 / 98$. A origem dessas emissoras vem muito antes da regulamentação: elas surgem numa luta por liberdade de expressão desde o período de redemocratização no Brasil, com as rádios livres que tiveram inspiração no movimento de rádios livres europeu. Ainda hoje, as rádios comunitárias enfrentam vários desafios para cumprirem minimamente o ideal de uma emissora do tipo.

Neste artigo, destacamos a importância da permanência da rádio comunitária enquanto instrumento de luta e construção democrática, a partir do entendimento do conceito de contrato de comunicação (CHARAUDEAU, 2005; 2018). Além disso, aplicamos esse conceito para analisar dois programas de duas emissoras da Baixada Fluminense: Espaço Aberto, da Rádio Serra Verde FM, localizada no distrito de Xerém, Duque de Caxias, e A Vida É Muito Mais, transmitido pela página no Facebook da Rádio Mirandela FM, localizada em Nilópolis. Ambos têm como características trabalhar cenários de vida da população: o primeiro a partir do debate de informações jornalísticas e o segundo com a discussão sobre cultura na região em que se encontra.

Quando nos aprofundamos na história e no desenvolvimento de rádios comunitárias, uma das questões mais debatidas diz respeito ao exercício comunitário do fazer rádio, entendendo-se essa prática como união entre habitantes de uma mesma comunidade numa busca por direitos e deveres cidadãos.

A comunicação comunitária vai além de informar. Ela tem como objetivo estimular moradores a analisar situações-problema de sua comunidade e se desafiarem a enfrentá-las, propondo ações concretas através da elaboração de um projeto coordenado por seus representantes comunitários. Dessa forma, criam-se condições e espaços para a prática do que chamamos de protagonismo popular (FERREIRA, 2019, s.p.).

\section{O que torna uma rádio comunitária?}

López Vigil (2003, p. 496), ao discutir o que torna comunitária uma rádio comunitária, afirma que o conceito deve ser ampliado para ser entendido a partir de interesses comuns, e não limites geográficos. $\mathrm{O}$ autor enumera que a rádio comunitária 
não pode ser entendida a partir da baixa potência ${ }^{3}$, nem ser restrita a determinadas frequências, uma vez que "mensagens democráticas podem viajar em qualquer onda" (LÓPEZ VIGIL, 2003, p. 499), seja ela digital, FM, ou até mesmo em programas veiculados em rádios comerciais. A falta de licença para transmissão também não pode ser fator limitante para as rádios comunitárias, já que nem todas conseguem vencer a burocracia reinante para ter a regulamentação. Outros dois pontos destacados por López Vigil dizem respeito à propriedade do meio e ao uso de publicidade. Sobre esses dois aspectos, o autor considera:

Tão comunitárias podem ser as rádios privadas quantos as públicas, as religiosas quanto às leigas, as universitárias, as sindicais, as de propriedade cooperativa, de organizações populares, de ONGs, ou até as de três rapazes malucos que se juntaram para fabricar seu próprio transmissor e ingressar na economia informal com sua emissorazinha de bairro (LÓPEZ VIGIL, 2003, p. 500).

López Vigil afirma que, em relação ao uso de publicidade, os anúncios servem para a sobrevivência das emissoras, pois assim conseguiriam manter seu funcionamento (ibid., 2003, p. 503). A partir do que foi apresentado, vemos que o autor foca no conteúdo transmitido pelas rádios, sejam elas nascidas ou não como comunitárias. Vale, para ele, se esse conteúdo traz ou não uma mensagem democrática e de cunho social a determinado lugar.

De qualquer forma, no caso brasileiro, as emissoras de tipo comunitário lutam há anos para conseguir o mínimo para continuarem atuando. Um dos entraves é, sem dúvida, a discussão sobre o uso da publicidade. No Brasil, a liberação para que as rádios comunitárias possam fazer uso de publicidade em suas programações está no senado por meio do projeto de lei $\mathrm{n}^{\circ}$ 666, de 2019. De autoria do senador Weverton Rocha (PDT/MA), o projeto prevê que as emissoras poderão ter patrocínio em forma de publicidade institucional pública ou privada, de interesse cultural, social ou de atos da

\footnotetext{
${ }^{3}$ Desde a lei que regulamenta a prática no Brasil, as rádios comunitárias têm potência estipulada em 25 watts. No entanto, está em tramitação na Câmara dos Deputados o projeto de lei n $10.637 / 2018$, que prevê o aumento da potência para 150 watts. O projeto foi aprovado pelo senado e segue aguardando apreciação do plenário. Disponível em: https://www.camara.leg.br/proposicoesWeb/fichadetramitacao?idProposicao=2182042. Acesso em: 4 maio 2020.
} 
administração pública. Estabelece, ainda, o tempo máximo de publicidade em $10 \%$ da programação diária ${ }^{4}$.

Já na América Latina em geral, a situação sobre a regulamentação das emissoras é de contínuo embate em cada um dos 20 países que compõem a região. Segundo Alvarez (2004 apud TORRES 2009, p. 14), "agora o grande inimigo a enfrentar são as distintas legislações que regulam a situação das rádios comunitárias na América Latina. À exceção da Colômbia, todos os países apresentam restrições, de uma ou outra maneira, ao trabalho destas emissoras".

As restrições, nas palavras de Nestor Busso, são de três tipos:

restrições na potência de emissão, na decisão do conteúdo e no uso de publicidade como forma de financiamento (a única forma que têm estas rádios de manter-se longe do alcance das influências e interesses políticos). Assim, por exemplo, no Chile, elas enfrentam restrições que as impedem de emitir com uma potência que supere um quilômetro de alcance; na Venezuela, é o governo que tem a última palavra sobre a programação de cada emissora; e no Peru a luta contra a norma que impôs o governo no ano passado que impedia a utilização de publicidade (BUSSO, 2004 apud TORRES, 2009, p. 14).

No entanto, cada uma das emissoras localizadas na América Latina continua o importante trabalho de desenvolvimento em suas regiões. As rádios comunitárias latinoamericanas têm um passado de luta que encontramos nas rádios educativas da Colômbia, rádios mineiras ou sindicais da Bolívia, revolucionárias em Cuba, Nicarágua e El Salvador e muitas outras emissoras: "na América Latina, as ondas da comunicação comunitária se encontram às vezes associadas às atividades arriscadas que só se justificam diante da grandeza dos ideais de paz, justiça e liberdade para todos. Experiências que transmitem esperança” (TORRES, 2009, p. 15).

López Vigil bem destaca as qualidades encontradas nas rádios comunitárias:

Quando uma emissora promove a participação dos cidadãos e defende seus interesses; quando responde aos gostos da maioria e faz do bom humor e da esperança a sua primeira proposta; quando informa com verdade; quando ajuda a resolver os mil e um problemas da vida cotidiana; quando em seus programas são debatidas todas as ideias e todas as opiniões são respeitadas; quando se estimula a diversidade

\footnotetext{
${ }^{4}$ O projeto aguarda relatoria desde novembro de 2019. Disponível em: https://www25.senado.leg.br/web/atividade/materias/-/materia/135185. Acesso em: $1^{\circ}$ maio 2020.
} 
cultural e não a homogeneização mercantil; quando a mulher protagoniza a comunicação e não é uma simples voz decorativa ou uma propaganda publicitária; quando não se tolera nenhuma ditadura imposta pelas gravadoras, nem mesmo a musical; quando a palavra de todos voa sem discriminações ou censuras - essa é uma rádio comunitária (LÓPEZ VIGIL, 2003, p. 506).

\section{Baixada Fluminense}

A Baixada Fluminense é uma região ligada a constantes embates sociais no estado do Rio de Janeiro: violência, problemas de segurança e condições dignas de vida convivem com uma busca de reconhecimento e atenção em demandas educacionais e culturais na maior parte de seus 13 municípios: Belford Roxo, Duque de Caxias, Guapimirim, Itaguaí, Japeri, Magé, Mesquita, Nilópolis, Nova Iguaçu, Paracambi, Queimados, São João de Meriti e Seropédica.

O Rio de Janeiro se expandiu geograficamente para cada um dos municípios citados, que se converteram numa grande área periférica da capital, com mais de três milhões de habitantes. Houve uma perspectiva de crescimento aventada num passado que viu expandir nas cidades da região o cultivo da cana de açúcar, laranja e a exploração mineral (FIGUERÊDO, 2004). A atual realidade está bem longe disso. Existe, na verdade, a "ausência de uma política de desenvolvimento econômico planejada pelos governos visando estimular e aproveitar seu potencial" (FIGUERÊDO, 2004, s.p.).

O dado mais alarmante na região que compõe a Baixada está no constante aumento da violência, diretamente ligado aos grupos de milícia que existem desde a década de 1950 (anteriormente intitulados de grupos de extermínio) e que, desde a década de 1990, migram para a política.

Essa população desembocou agora nessas pessoas [milicianos]. Já desembocava antes, a baixada sempre assistiu esses matadores tendo uma carreira de sucesso, e agora essas carreiras estão extrapolando o nível local e chegam a essa dimensão nacional. Mas, ao meu ver, isso foi construído. Poderia dizer que há uma lógica miliciana e uma concepção miliciana que passa a dominar a sociedade brasileira (ALVES, 2019, s.p.). 
De acordo com o pesquisador, essa concepção envolve todo um modo de vida na rotina de qualquer pessoa: desde venda de gás de cozinha até o vínculo com vários serviços públicos, a milícia domina muitos desses lugares.

Para vencer o desafio de ser vista única e exclusivamente como uma região periférica e violenta, há na Baixada uma intensa prática de atividades culturais e atuação de organizações sociais como forma de estimular aspectos de uma vivência cidadã. E é nesse âmbito que surgem as rádios comunitárias, procurando mostrar que é possível trabalhar uma comunicação local, voltada para as questões práticas de cada uma dessas cidades. Não falamos apenas em relação aos problemas que as cidades apresentam, mas também com a produção cultural e local.

\section{Rádios comunitárias na Baixada Fluminense}

O número de rádios comunitárias nos 13 municípios da Baixada Fluminense é incerto. Há registro de dez emissoras em funcionamento no site da $A_{\text {natel }}{ }^{5}$, mas o número deve ser bem maior, considerando-se que muitas emissoras comunitárias funcionam sem regulamentação. No Brasil, há mais de 30 mil rádios comunitárias operando e estão presentes, segundo Orlando Berti, em todos os estados federativos.

Em praticamente todas essas quase seis mil cidades, incluindo suas zonas rurais, há uma FM comunitária funcionando, tendo penetração, geralmente com grande influência, no dia a dia de suas populações. Em alguns casos são os únicos meios de comunicação que retratam sobre o local e o regional (BERTI, 2019, p. 151).

As rádios comunitárias, sem dúvida, vivem uma relação próxima com a comunidade: conhecimento das pessoas, dos lugares, dos problemas locais. Mais que conhecer quem é quem no espaço onde a rádio está inserida, é preciso haver proximidade, portas abertas para que seja possível trabalhar a informação local e as melhorias naquela localidade. É preciso dizer que as melhorias nos locais onde as rádios comunitárias estão inseridas envolvem não apenas assuntos como mobilidade, saúde,

\footnotetext{
${ }^{5}$ Disponível em: https://sistemas.anatel.gov.br/easp/Novo/Consulta/Tela.asp?OP=E\&nav=13\&c=1\&pref= Acesso em: 10 abr. 2020.
} 
educação, política, entre outros, de fato assuntos muito caros ao atual momento no cenário brasileiro; envolvem também a relação com o espaço de cultura e lazer, escape e respiro na luta diária. Habitar um lugar, ter a vida cotidiana em casa, na rua, no bairro, envolve o direito ao bem-estar, a usufruir de condições e situações que alcancem isso.

Nesse sentido, é pelo viés da proximidade que as rádios comunitárias se fazem importante onde funcionam. Proximidade não apenas no sentido figurado, mas proximidade das situações cotidianas. Não é à toa que o rádio tem a imagem de companheiro e amigo do ouvinte.

A imagem do rádio como companheiro e amigo revela, antes, que o veículo consegue estabelecer com o receptor contratos que têm ingredientes (cláusulas) a mais do que o jornal ou a própria televisão. Relações marcadas pela demonstração de carinho, fidelidade e agradecimento. A estratégia da recriação da ambiência e uma ação mais direta sobre o imaginário do receptor propiciam isso, de certa maneira. O rádio é um convite permanente à imaginação, ao envolvimento, e mesmo, à cumplicidade na realização do processo enunciativo (SALOMÃO, 2003, p. 26).

Já em Berti (2019, p. 8), a proximidade e fidelização com o receptor são elementos importantes para que os ideais comunitários se façam presentes na prática das rádios comunitárias:

O estar próximo às comunidades ajuda as emissoras comunitárias a poderem fazer mais pelos ambientes nos quais estão inseridas. Isso é dado porque a maioria (ou quase totalidade) dos agentes comunitários dessas emissoras estão inseridos no próprio ambiente local, conhecendo a fundo as demandas comunitárias, muitas vezes tendo sido nascidos e criados naqueles ambientes. Fatos que instigam maiores compromissos comunicacionais dessas rádios.

Destaque-se, ainda, que o perfil do ouvinte de rádio comunitária não se estagnou - pelo contrário, avançou conforme a evolução tecnológica. Hoje temos as rádios funcionando no esquema tradicional de frequência modulada e também na internet (algumas migraram completamente para o ambiente da web). O ouvinte, assim, é agora um ouvinte-internauta, conforme descreve Débora Lopez (2010, p. 115):

O rádio não fala para um ouvinte passivo, mas para alguém que deseja participar, contribuir - mais do que o fazia até então. O ouvinte agora também ouvinte-internauta - busca outras fontes de informação, cruza, contesta, discute, corrige, atualiza, conversa com o jornalista 
que está no ar. Mais que nunca, o ouvinte participa. [...] Hoje eles [ouvintes] compartilham os mesmos espaços e ambientes, muitas vezes no mesmo círculo de relações, através de redes sociais. Desta forma, o ouvinte, que antes glorificava, idealizava e mitificava o comunicador, tem a oportunidade de passar a vê-lo de maneira mais próxima, já que se lhe permite o diálogo, a interação.

\section{Contrato de comunicação}

De acordo com Patrick Charaudeau, todo discurso depende de uma série de condições específicas que vão propiciar trocas entre as pessoas envolvidas. A situação de comunicação, nas palavras do autor, é a principal referência para que isso ocorra.

Como poderiam trocar palavras, influenciar-se, agredir-se, seduzir-se, se não existisse um quadro de referência? Como atribuiriam valor a seus atos de linguagem, como construiriam sentido, se não existisse um lugar ao qual referir as falas que emitem, um lugar cujos dados permitissem avaliar o teor de cada fala? A situação de comunicação é como um palco, com suas restrições de espaço, de tempo, de relações, de palavras, no qual se encenam as trocas sociais e aquilo que constitui o seu valor simbólico (CHARAUDEAU, 2018, p. 67).

Nessa linha de pensamento, ao escutarmos um programa de rádio, nos deparamos com a fala do locutor em seu palco de atuação, a emissora ou qualquer ambiente externo, que se dirige a um público. Este, por sua vez, deve reconhecer aquilo que é dito e ter ciência dos códigos utilizados para, a partir do som, visualizar as falas e o que está além delas - o rádio nos leva à sensorialidade, à capacidade de imaginar aquilo que ouvimos:

Produzimos imagens, não apenas no sentido de que criamos objetos imagéticos, mas também porque fabricamos a conexão em nossas cabeças entre as coisas e as figuras, sonoras ou visuais, dessas coisas. Portanto, para que exista uma imagem é necessário um ato de performance de quem escuta ou de quem vê (IAZETTA, s.a., p. 20).

Voltando a Charaudeau, há na prática comunicativa um quadro de cointencionalidade no qual, no caso de emissoras de rádio, tanto quem fala quanto quem escuta conhece e aceita as restrições da situação de comunicação: 
O necessário reconhecimento recíproco das restrições da situação pelos parceiros da troca linguageira nos leva a dizer que estes estão ligados por uma espécie de acordo prévio sobre os dados desse quadro de referência. Eles se encontram na situação de dever subscrever, antes de qualquer intenção a estratégia particular, a um contrato de reconhecimento das condições de realização da troca linguageira em que estão envolvidos: um contrato de comunicação. Este resulta das características próprias à situação de troca, os dados externos, e das características discursivas decorrentes, os dados internos (CHARAUDEAU, 2018, p. 68).

Os dados externos se constituem a partir de regularidades comportamentais e pelas constantes que surgem nas trocas e se mantêm estáveis. Charaudeau afirma que ambas as situações "são confirmadas por discursos de representação que lhes atribuem valores e determinam assim o quadro convencional no qual os atos de linguagem fazem sentido" (CHARAUDEAU, 2018, p. 68). Há quatro categorias para os dados externos:

1. Condição de identidade - a troca depende dos sujeitos que participam do ato de comunicação (quem fala a quem?);

2. Condição de finalidade - é preciso haver um objetivo no ato de comunicação (estamos aqui para dizer o quê?);

3. Condição de propósito - "é a condição que requer que todo ato de comunicação se construa em torno de um domínio de saber" (ibid., p. 69). A pergunta que se faz é: do que se trata?

4. Condição de dispositivo - "é a condição que requer que o ato de comunicação se construa de uma maneira particular" (ibid., p. 69). Que lugares físicos são ocupados para o ato de comunicação?

Em relação aos dados internos do contrato de comunicação, o autor aponta que eles estão na esfera discursiva; respondem à pergunta: como dizer? Ocupam o espaço de locução, o espaço de relação e o espaço de tematização.

1. Espaço de locução - "o sujeito falante deve resolver o problema da "tomada da palavra"” (ibid., p. 71). Aqui, justifica sua posição como sujeito falante e identifica o destinatário ao qual se dirige;

2. Espaço de relação - é o momento em que se estabelecem "relações de força ou aliança, de exclusão ou de inclusão, de agressão ou de conivência com o interlocutor" (ibid., p. 71). 
3. Espaço de tematização - é onde se fala do tema da troca; o sujeito falante toma partido do tema, aceitando ou não, e escolhe como vai atuar em relação a esse tema.

Nos parágrafos a seguir, registramos o funcionamento de duas emissoras comunitárias na Baixada: a Serra Verde, de Xerém, distrito de Duque de Caxias; e a Rádio Mirandela, de Nilópolis. Ambas possuem uma forte atuação nas cidades em que se encontram e são emissoras comunitárias consolidadas na região. Aplicamos o conceito de contrato de comunicação de Patrick Charaudeau (2018) como linha metodológica para verificar a importância dessas emissoras em uma comunicação propositiva e cidadã e entender como se dá a presença dos ouvintes nas emissoras.

\section{Rádio Serra Verde FM}

Localizada no distrito de Xerém, Duque de Caxias, a Rádio Serra Verde 98,7 FM funciona desde maio de 2003 e cobre a região de Xerém e municípios vizinhos. Funciona na área rural da região e, além da cobertura em frequência modulada, também possui site na internet e sistema de alto-falantes nas ruas e praças de Mantiquira e Xerém $^{6}$. Em 2004, o idealizador da emissora, Reinaldo Santos, começou o trâmite para tornar a Serra Verde regulamentada, o que ocorreu apenas em $2010^{7}$.

A rádio funciona 24 horas por dia e, para se manter, utiliza os apoios culturais obtidos a partir do comércio local. Atualmente, há uma equipe de sete pessoas que se reveza entre programas musicais e o programa Espaço Aberto, que atende as demandas dos ouvintes. Nesse programa, o ouvinte entra em contato por Whatsapp, redes sociais e telefonemas.

De acordo com um dos apresentadores, Frank Bezerra, a programação musical trabalha com "sertanejo raiz, flashbacks, música contemporânea, MPB, música internacional antiga e também atual, não coisa muito que bate na cabeça da pessoa, é mais tranquila"8.

\footnotetext{
${ }^{6}$ Disponível em: http://www.serraverdefm.com.br/sobre-nos. Acesso em: 15 maio 2020.

${ }^{7}$ Segundo Reinaldo, que cuidou de toda a parte burocrática para conseguir a regulamentação, a licença provisória saiu em 2010 e a definitiva, em 2016.

${ }^{8}$ Entrevista cedida às autoras em fevereiro de 2019.
} 
O programa Espaço Aberto é o mais representativo em relação ao trabalho com a comunidade. Vai ao ar às sextas-feiras, das 9 às 12 horas. A apresentação é de Reinaldo Santos e conta com dois ou três debatedores.

\begin{abstract}
Quando a gente reformulou o programa eu criei uma ideia de fazer uma mesa para apresentar o programa para não ficar preso a uma pessoa só. Chamei o representante de cada setor da comunidade. Tem um que foi presidente da associação de moradores, a outra do conselho municipal de saúde, o outro que está sempre por dentro das coisas de Xerém, apesar de não ser morador, tem uma bióloga que vem, que já fez serviço aqui de horta comunitária em uma associação aqui. ${ }^{9}$
\end{abstract}

Há ainda o quadro repórter comunitário, para ir às ruas conversar com os moradores: o repórter leva um telefone e um rádio-retorno para a comunicação. Reinaldo Santos explica que a ideia é parte do plano de incentivar maior participação dos moradores com a emissora.

Um caso que mostra a importância da rádio comunitária na região ocorreu em 2013 durante as fortes chuvas em Xerém. Reinaldo lembra que a cidade estava sem comunicação e alguns moradores procuraram a emissora para pedir ajuda e chamar os bombeiros: "Agora, toda vez que chove, as pessoas ligam logo pra rádio, deixam mensagem na página”, diz Reinaldo.

\title{
6.1. Rádio Serra Verde FM nas redes sociais
}

A página Rádio Serra Verde FM no Facebook tem 6.959 curtidas e 7.105 seguidores, incluindo pessoas que moram em outros estados. O Twitter @SerraVerde987FM possui 17 seguidores (não atualiza as informações desde 2017), e a página da rádio no Instagram, @serraverdefmxerem, tem 184 seguidores e 27 publicações. ${ }^{10}$ Os dados dão a entender que a rádio tem predominância no meio tradicional de transmissão, pelas ondas de frequência modulada, e o Facebook é a rede social mais utilizada para passar informações sobre a emissora.

\footnotetext{
${ }^{9}$ Reinaldo Santos em entrevista cedida às autoras em fevereiro de 2019.

${ }^{10}$ Dados de 21 de setembro de 2020.
} 


\subsection{Programa Espaço Aberto ${ }^{11}$}

O programa é apresentado semanalmente, às sextas-feiras, das 9 às 12 horas, dividido em três blocos. No programa do dia 22 de março de 2019, os assuntos discutidos foram: conferência municipal de saúde em Duque de Caxias; dispensa de vistos do governo brasileiro para turistas dos EUA, Canadá, Austrália e Japão; discriminação de funcionários da Alerj com a deputada Dani Monteiro; Arco Metropolitano; momento político no Brasil; posse a deputados presos no Rio de Janeiro; protesto contra a reforma da previdência; assessores de assuntos religiosos nomeados por prefeito de Belford Roxo; Procon de Petrópolis notificando estabelecimentos com produtos vencidos; e trânsito em Xerém.

A estrutura do programa é tradicional, com um apresentador e os debatedores. As notícias são escolhidas pela importância do momento e importância para a região. Assim, ao mesmo tempo que há uma discussão sobre a liberação de vistos a turistas estrangeiros, também se discute a conferência municipal de saúde em Duque de Caxias. O apresentador, Reinaldo, faz a leitura da notícia principal e, na sequência, convida os colegas a debaterem o assunto. Nesse dia, participaram como debatedores Luis Fares e Roberto Santos, ambos moradores da Baixada e atuantes em rádios comunitárias.

Em todos os blocos há participação dos ouvintes para agradecer por uma melhoria alcançada por meio da emissora - caso do ouvinte Samuel, por exemplo, que ligou para falar de um problema na sua rua que acabou sendo sanado com ajuda da rádio. Os ouvintes também são convidados a darem a opinião sobre os diversos assuntos em pauta. Para incentivá-los, há promoções com prêmios, como um frango assado ou uma consulta oftalmológica, que foi o caso no dia desse programa. Nessa edição, 11 ouvintes participaram do programa, diretamente por telefone, conversando com os apresentadores, ou por mensagens pelo Whatsapp.

Houve ainda a participação de duas mulheres repórteres voluntárias da emissora: Rosângela Costa, bióloga e professora, que fez a cobertura da conferência municipal de saúde em conjunto com Vilna Ferreira, também repórter voluntária e conselheira de

\footnotetext{
${ }^{11}$ O programa foi escolhido para análise por ser o programa jornalístico da emissora que mais trabalha com as situações cotidianas dos ouvintes na cidade. O programa do dia 22 de março de 2019 foi escolhido de forma aleatória.
} 
saúde no município. Elas entrevistaram participantes da conferência, conversaram com os apresentadores do programa e informaram sobre os debates realizados no evento.

Nessa edição, foram ao ar 30 intervenções de apoios culturais, demonstrando que a emissora tem popularidade no comércio local e que este aposta na Serra Verde FM como espaço de divulgação de seus produtos.

\section{Rádio Mirandela FM}

A Rádio Mirandela FM existe desde 1994, mas com outro nome: Aparecida FM. De 1997 até 2007 a rádio permaneceu fechada e parada, decisão tomada por não terem conseguido a autorização legal para funcionar. O processo só foi retomado em 2006, e em 2007 a concessão foi liberada. Com a regulamentação, foi preciso utilizar um novo nome, e a partir do ano de 2007 a antiga rádio Aparecida FM se tornou a rádio comunitária Mirandela $\mathrm{FM}^{12}$.

Localizada em Nilópolis, no interior de uma igreja católica, a Mirandela é a rádio comunitária de baixa frequência que representa a região. Fabiano Maranhão é o coordenador da rádio e faz também a operação de áudio. Em 2019, havia 20 voluntários de diversas faixas etárias e áreas de trabalho/estudo para levar ao ar cerca de 20 programas em 12 horas de programação por dia. Há também programas gravados e transmitidos nos horários vagos.

A Rádio Mirandela FM é a única rádio comunitária com regulamentação do município de Nilópolis. Por conta de toda a sua história, é importante mencionar o tipo de relação que existe com a Paróquia de Nossa Senhora Aparecida. De acordo com Fabiano, a paróquia atua como apoiadora do trabalho da emissora, uma vez que as rádios comunitárias não podem ter ligação com qualquer tipo de religião ou grupo político.

Ao longo dos anos, com a gestão de alguns representantes da paróquia que acreditavam na importância da Mirandela para dialogar com os moradores, a rádio recebeu auxílio de freis que abraçaram a ideia. O atual frei é uma das pessoas que ajudaram, apoiando-a durante anos, com o estúdio e outras necessidades para o funcionamento da rádio.

\footnotetext{
${ }^{12}$ Mirandela é o nome da estrada onde se localiza a emissora.
} 
Hoje, a rádio sobrevive parcialmente por meio de apoios culturais. Depois de diálogos entre a diretoria e o posicionamento da igreja de querer contribuir, foi decidido que o frei Walter Ferreira ajudaria nos custos da rádio: compraram a casa, adaptaram para o estúdio e a rádio funciona com a colaboração dos próprios voluntários e pessoas da equipe que cedem e ajudam com equipamentos, computadores e outros materiais.

\subsection{Programação}

Entrevistas, assuntos de utilidade pública, noticiário, quadros interativos, informações da área de saúde, prestação de serviços e quadros musicais fazem parte da diversa programação da Mirandela.

A rádio já realizou programas com debates sobre depressão e suicídio com recorde de audiência, chegando a dois mil ouvintes. Segundo Fabiano, isso reforça a necessidade de fazer esse diálogo com os ouvintes. Ele enumera os programas que já foram ao ar na rádio, que apresentaram: conteúdo sobre inclusão, saúde, autismo, prévestibulares sociais; entrevistas com psicólogos, líderes religiosos candomblecistas, umbandistas, católicos, evangélicos e judeus; debates sobre a questão da previdência, questões sociais e questões específicas da realidade dos moradores daquela região.

\subsection{Mirandela nas redes sociais}

Devido ao alcance reduzido e baixa frequência, as rádios comunitárias buscam alternativas para chegar até pessoas de outras partes do estado e do país. Uma das estratégias da Mirandela é o uso das redes sociais. No período de pandemia da Covid19, por exemplo, a Rádio Mirandela FM está fechada, mas dispõe de apresentações de lives no Facebook como forma de manter-se atuante.

A página Rádio Mirandela FM 98,7 no Facebook possui 4.441 curtidas e 5.296 seguidores, incluindo pessoas que moram em outros estados, as quais interagem e acompanham a transmissão dos programas. O Twitter @ radiomirandelafm conta com 358 seguidores (a postagem mais recente é de 2019), e a página da rádio no Instagram tem 398 seguidores e 118 publicações. ${ }^{13}$

\footnotetext{
${ }^{13}$ Dados de 21 de setembro de 2020.
} 
As lives são uma ferramenta estratégica importante para a interação com o público, que pode reagir e comentar em tempo real durante a programação. Dessa forma, cria-se certo tipo de proximidade com o ouvinte, ainda que esteja longe do local onde a rádio funciona.

\subsection{A Vida É Muito Mais}

O especial A Vida É Muito Mais foi uma live apresentada em quatro edições na página da Rádio Mirandela FM. ${ }^{14}$ Começou em 29 de maio, durante a pandemia de Covid-19, e por isso foi transmitido da casa do apresentador Eli Geovane ${ }^{15}$, às 21 horas. Eli Geovane é assistente social e criador de conteúdo digital. Morador de Nilópolis, ele possui o canal de compartilhamento A Vida É Muito Mais, um canal do YouTube no qual ele fala de experiências sobre a vida e ajuda empreendedores de todo o Brasil a divulgar melhor seu trabalho.

Desse canal, surgiu a ideia de transmissão também pela página da Mirandela. $A$ Vida É Muito Mais foi produzido por Eli e transmitido na página da rádio no Facebook como forma de agregar público. Segundo o assistente social, tanto seu trabalho na emissora quanto as lives tiveram que parar devido a sua candidatura a vereador em Nilópolis. ${ }^{16}$

Para esta análise escolhemos a live de estreia no canal, que pode ser enquadrada no gênero de entretenimento por promover a cultura da região e ter um formato mais solto e de humor. No dia de estreia, a edição contou com os seguintes temas: quadros de humor; entrevista com Flávio Lemos, integrante da banda musical Dona Zezé, uma banda móvel que se apresenta em ruas, trem e metrô no Rio de Janeiro; dicas sobre o que fazer na quarentena, com Guilherme Henrique; dicas de livros, músicas e jogos de videogame; entrevista com integrantes da ONG Heróis e Princesas da Alegria, que faz intervenções em hospitais, asilos e creches; quadro "Seu talento é muito mais", que divulga talentos de moradores; quadro "Eli recomenda", com divulgação de comércio

\footnotetext{
${ }^{14} \mathrm{O}$ especial foi escolhido para análise por ser de entretenimento e ter começado no período da pandemia de Covid-19. A emissora está fechada desde o início do isolamento social, em março de 2020.

${ }^{15} \mathrm{O}$ assistente social está há oito anos na Mirandela como voluntário e lá apresenta o programa Encontrão Jovem, um programa católico.

${ }^{16}$ Entrevista cedida às autoras em 28 de setembro de 2020.
} 
local. Os participantes dessa edição são moradores ou da Baixada Fluminense ou de Campo Grande, na Zona Oeste do Rio de Janeiro.

A interação com o público ocorreu a todo instante. Eli fez a leitura das mensagens enviadas pelo Facebook e brincou bastante com o público. A live teve 554 visualizações $^{17}, 49$ curtidas e 246 comentários na página da emissora. O apresentador é jovem, conhece a região e mostra bastante entusiasmo com o trabalho. Ele encerra o programa cantando uma música previamente combinada com seu público.

\section{Contrato de comunicação nas emissoras}

\begin{tabular}{|c|c|c|c|}
\hline \multicolumn{2}{|c|}{$\begin{array}{l}\text { Rádio Serra Verde FM } \\
\text { Programa Espaco Aberto }\end{array}$} & \multicolumn{2}{|c|}{$\begin{array}{l}\text { Rádio Mirandela FM } \\
\text { Programa } A \text { Vida É Muito Mais }\end{array}$} \\
\hline Dados externos & Dados internos & Dados externos & Dados internos \\
\hline $\begin{array}{l}\text { Identidade } \\
\text { O apresentador } \\
\text { principal é quem } \\
\text { conduz as ações } \\
\text { de fala e } \\
\text { incentiva os } \\
\text { ouvintes a } \\
\text { participarem do } \\
\text { contrato de } \\
\text { comunicação. }\end{array}$ & $\begin{array}{l}\text { Locução } \\
\text { O apresentador } \\
\text { que faz a } \\
\text { mediação do } \\
\text { programa entre } \\
\text { os debatedores e } \\
\text { os ouvintes. }\end{array}$ & $\begin{array}{l}\text { Identidade } \\
\text { Um único } \\
\text { apresentador } \\
\text { conduz o ato de } \\
\text { comunicação e } \\
\text { convida o público a } \\
\text { interagir com ele. }\end{array}$ & $\begin{array}{l}\text { Locução } \\
\text { O apresentador faz } \\
\text { todas as passagens, } \\
\text { chamando quadros, } \\
\text { entrevistando } \\
\text { convidados e } \\
\text { falando com } \\
\text { ouvintes } \\
\text { internautas. }\end{array}$ \\
\hline $\begin{array}{l}\text { Finalidade } \\
\text { Discussão de } \\
\text { temas relevantes } \\
\text { à comunidade de } \\
\text { Xerém. }\end{array}$ & $\begin{array}{l}\text { Relação } \\
\text { O apresentador, } \\
\text { Reinaldo, } \\
\text { consegue } \\
\text { estabelecer um } \\
\text { espaço de } \\
\text { entendimento e } \\
\text { respeito junto a } \\
\text { seus colegas } \\
\text { debatedores e } \\
\text { também junto ao } \\
\text { público ouvinte, } \\
\text { mesmo que não } \\
\text { concorde com o } \\
\text { que é dito. }{ }^{18}\end{array}$ & $\begin{array}{l}\text { Finalidade } \\
\text { Discussão de temas } \\
\text { de entretenimento } \\
\text { com: humor, } \\
\text { cultura, } \\
\text { comportamento. }\end{array}$ & $\begin{array}{l}\text { Relação } \\
\text { O apresentador, Eli } \\
\text { Geovane, se mostra } \\
\text { simpático, } \\
\text { entusiasmado, } \\
\text { deixando o } \\
\text { programa em alto } \\
\text { astral e leve. }\end{array}$ \\
\hline
\end{tabular}

\footnotetext{
${ }^{17}$ Dados de 23 de setembro de 2020.

${ }^{18}$ No segundo bloco do programa, o ouvinte Fábio responde à pesquisa do dia: você é a favor ou contra a liberação de vistos no Brasil para turistas de EUA, Canadá, Austrália e Japão? O ouvinte explica porque é a favor da liberação de vistos, e Reinaldo, que é contra, conversa com o ouvinte de forma educada e acatando a opinião emitida.
} 


\begin{tabular}{|c|c|c|c|}
\hline $\begin{array}{l}\text { Propósito } \\
\text { Notícias } \\
\text { jornalísticas } \\
\text { diversas, notícias } \\
\text { da região, } \\
\text { reclamações de } \\
\text { ouvintes, } \\
\text { promoções. }\end{array}$ & $\begin{array}{l}\text { Tematização } \\
\text { O programa é } \\
\text { emitido durante } \\
\text { três horas e é } \\
\text { organizado em } \\
\text { três blocos. } \\
\text { Cada bloco traz } \\
\text { assuntos } \\
\text { previamente } \\
\text { organizados, } \\
\text { com espaço para } \\
\text { opinião dos } \\
\text { debatedores e } \\
\text { dos ouvintes que } \\
\text { participam. }\end{array}$ & $\begin{array}{l}\text { Propósito } \\
\text { Mostrar os } \\
\text { moradores da } \\
\text { Baixada em } \\
\text { trabalhos que } \\
\text { envolvem humor, } \\
\text { cultura, ação social } \\
\text { etc. }\end{array}$ & $\begin{array}{l}\text { Tematização } \\
\text { A live dura pouco } \\
\text { mais de uma hora, } \\
\text { organizada pelo } \\
\text { apresentador com } \\
\text { muito dinamismo. } \\
\text { Isso pode ser } \\
\text { comprovado com o } \\
\text { uso de quadros } \\
\text { diversos: dicas, } \\
\text { cultura, ação social, } \\
\text { perguntas aos } \\
\text { ouvintes } \\
\text { internautas, humor } \\
\text { e música. }\end{array}$ \\
\hline $\begin{array}{l}\text { Dispositivo } \\
\text { Rádio em } \\
\text { frequência } \\
\text { modulada e com } \\
\text { transmissão } \\
\text { também online. }\end{array}$ & & $\begin{array}{l}\text { Dispositivo } \\
\text { Internet, live por } \\
\text { rede social - } \\
\text { Facebook. }\end{array}$ & \\
\hline
\end{tabular}

Nas duas situações, os locutores, sujeitos que emitem a fala a partir do estúdio da emissora (caso Serra Verde) ou do ambiente de sua residência (caso Mirandela), estão imersos no palco de onde comunicam seus dizeres, restritos por um tempo de duração do programa, pelo espaço de onde falam e pelas relações que se estabelecem nessa espécie de encenação que ocorre durante a apresentação dos programas analisados.

O contrato de comunicação se faz presente nos aspectos citados, que são detalhados nos dados externos. Os dados externos, como vimos, trabalham com tudo que traz uma regularidade e constância nas trocas. Em ambos os programas, isso ocorre a partir do chamamento do ouvinte. O ouvinte é convocado em presença, é lembrado a cada abraço e é estimulado à participação, seja por meio de telefonemas ou mensagens pelo Whatsapp ou Facebook.

A forma como isso ocorre é por meio dos dados internos, nos quais localizamos o jeito dos locutores de se expressar e de trabalhar a linguagem para relacionar-se com o público e com os temas trabalhados. Se na Rádio Serra Verde FM isso ocorre na condução de um programa jornalístico que discute notícias, opina e envolve o ouvinte no cotidiano da cidade, portanto com um tom sério; na Rádio Mirandela, ocorre no viés 
do entretenimento, com humor, cultura e comportamento, mostrando que as cidades da Baixada possuem um cotidiano repleto de situações diversas.

Como se percebe, as rádios aqui apresentadas fazem uso do avanço tecnológico: saem de um momento analógico e passam a funcionar também de forma virtual, com o uso de sites e redes sociais. Isso é positivo, pois dessa forma conseguem atender a dois públicos distintos: o público que ouve a emissora nos aparelhos de rádio e o público que tem acesso à internet, conforme Kischinhevsky (2016, p. 13-14):

O rádio é hoje um meio de comunicação expandido, que extrapola as transmissões em ondas hertzianas e transborda para as mídias sociais, o celular, a TV por assinatura, sites de jornais, portais de música. A escuta se dá em frequência modulada (FM), ondas médias (AM), curtas e tropicais, mas também em telefones celulares, tocadores multimídia, computadores, notebooks, tablets; pode ocorrer ao vivo (no dial ou via streaming) ou sob demanda (podcasting ou através da busca em arquivos ou diretórios).

Notamos que os ouvintes da Rádio Serra Verde FM e da Mirandela fazem, sim, uso do modelo tradicional de escuta, via FM, mas acompanham também as emissoras via internet, pelos celulares ou pelos posts nas redes sociais; em ambas, o Facebook é o mais utilizado.

\section{Considerações finais}

A linguagem radiofônica é trabalhada de forma natural nas emissoras apresentadas. Cada qual a seu estilo procura ter, talvez de forma instintiva, o espaço para a palavra falada, os efeitos, a música e o silêncio. Percebemos que tanto na Rádio Serra Verde quanto na Mirandela há uma estreita relação com o lugar de onde transmitem. Os apresentadores levam ao ouvinte a informação local, que chega pelo celular, por mensagens na internet, por leituras de sites de notícia ou por entrevistas que são feitas diariamente.

Um dos problemas em relação ao conteúdo das emissoras é a reprodução de um estilo de programação realizado pela grande mídia. Na verdade, é algo que se resolveria a partir de capacitações aos integrantes das emissoras. Já houve no passado esse tipo de 
iniciativa, mas hoje as emissoras contam com poucos recursos para aprimorarem seus conteúdos. Como bem lembra Peruzzo (1998, p. 13):

\begin{abstract}
As rádios comunitárias não pretendem competir com as emissoras convencionais. Querem mesmo é oferecer às comunidades conteúdos de cunho cultural e educativo que as outras não têm se interessado em privilegiar. Em sua dinâmica vêm servindo de espaço para o aprendizado da cidadania, ao proporcionar mecanismos para participação da população nas várias etapas do processo de comunicação, tais como na gestão dos veículos e no planejamento e produção de programas.
\end{abstract}

As emissoras comunitárias realizam um trabalho essencial para a população. Mais essencial ainda quando nos referimos a uma região extremamente carente de recursos, como é a Baixada Fluminense. São essas rádios que levam às autoridades as situações emergenciais apontadas pelos moradores. Claro que aqui estamos falando das emissoras que cumprem fielmente o caráter comunitário de forma independente e propositiva. Isso pode ser notado, por exemplo, na Rádio Serra Verde ${ }^{19}$ ao noticiarem uma intervenção do Procon em Petrópolis que autuou estabelecimentos com alimentos vencidos, e logo uma ouvinte pergunta sobre como acionar o Procon em Xerém. O apresentador principal pesquisa e, assim que consegue a informação, a passa no ar. Outro ouvinte reclama da falta de energia elétrica no seu bairro. $\mathrm{O}$ apresentador liga para a companhia de energia elétrica e não obtém resposta. $\mathrm{O}$ fato também é comentado no ar. Esses exemplos demonstram que a rádio cumpre o papel de ser porta-voz dos moradores do lugar, levando a diversas instituições os cenários apresentados e cobrando resoluções mais rápidas.

Uma rádio comunitária agrega qualidade quando faz uma programação que atende as necessidades de seu público e quando fala com esse público com conhecimento de causa. Quanto mais local é a programação, mais próxima estará de um processo dialógico com o ouvinte. Ao acompanhar a programação de sua cidade, o ouvinte se percebe fazendo parte daquela situação. A proximidade com o ouvinte é uma das principais características da rádio, e é por isso que o locutor fala com uma infinidade de pessoas como se estivesse falando com cada um em particular. Isso gera sensações de visibilidade e importância; no caso da Baixada ainda mais, pois as notícias

\footnotetext{
${ }^{19}$ Programa Espaço Aberto, acima analisado.
} 
são locais e não são apenas notícias e assuntos de violência comumente veiculados na grande mídia.

A live A Vida É Muito Mais da Rádio Mirandela traz assuntos essenciais para qualquer sociedade: estimula o riso, o bem-estar e o conhecimento cultural da região, mostrando trabalhos de pessoas que dificilmente estariam na mídia, mas que têm espaço na rádio comunitária. Em período de pandemia, é questão de sobrevivência acompanhar um programa que leva a alegria às casas, ainda mais quando mostra o talento de pessoas da região.

Sem dúvida, a sobrevivência se impõe às emissoras neste momento. Sobrevivência não apenas financeira, mas também em termos de sedução de uma ampla parcela de moradores para que tenham as rádios como suas. A participação e a abertura de portas devem ser estimuladas para um trabalho cidadão e envolvente, com vistas ao cumprimento do ideal comunitário das emissoras.

Em todo caso, há de se entender que, em um momento de distanciamento social, o uso das redes sociais e o estímulo contínuo à participação conseguem integrar os sujeitos do ato de comunicação e seus destinatários numa rede de troca e relação constantes. Nesse sentido, tanto a Rádio Serra Verde FM de Xerém quanto a Rádio Mirandela FM de Nilópolis conseguem levar uma comunicação plural e cidadã a seus ouvintes.

\section{Referências}

ALVES, José Cláudio Souza. Como atuam as milícias por dentro e por fora do estado. Disponível em: https://www.brasildefato.com.br/especiais/como-atuam-as-milicias-por-dentroe-por-fora-do-estado. Acesso em: 24 abr. 2020.

ANATEL - Agência Nacional de Telecomunicações. Sistema de Consultas. Disponível em: https://sistemas.anatel.gov.br/easp/Novo/Consulta/Tela.asp?OP=E\&nav=13\&c=1\&pref. Acesso em: $1^{\circ}$ maio 2020.

BALSEBRE, Armand. A linguagem radiofônica. In: MEDITSCH, Eduardo. Teorias do rádio: textos e contextos. Florianópolis: Insular, 2005. p. 327-336.

BAUMWORCEL, Ana. Armand Balsebre e a teoria expressiva do rádio. In: MEDITSCH, Eduardo. Teorias do rádio: textos e contextos. Florianópolis: Insular, 2005. p. 337-346.

BERTI, Orlando Maurício de Carvalho. Vinte e um anos da lei das rádios comunitárias no Brasil. Pontos e contrapontos. Revista Rádio-Leituras, Mariana/MG, v. 10, n. 2, p. 150-171, jul./dez. 2019. 
BRASIL. Câmara dos Deputados. Projeto de lei no 10.637/2018. Altera a lei no 9.612, de 19 de fevereiro de 1998, para aumentar o limite de potência de transmissão e qualidade de canais designados para a execução do Serviço de Radiofusão Comunitátia. Disponível em: https://www.camara.leg.br/proposicoesWeb/fichadetramitacao?idProposicao=2182042. Acesso em: 4 maio 2020.

BRASIL. Senado Federal. Projeto de lei no 666/2019. Altera a lei $n^{\circ} 9.612$, de 19 de fevereiro de 1998, que institui o Serviço de Radiofusão Comunitátia, para permitir a veiculação de privacidade. Disponível em: https://www25.senado.leg.br/web/atividade/materias//materia/135185. Acesso em: $1^{\circ}$ maio 2020.

CARVALHO, Marcus Aurélio. Rádios comunitárias em crise existencial: linguagem e afetos na era do ouvinte comunicador. 173 p. Dissertação de mestrado, Programa de Pós-graduação em Mídia e Cotidiano, Universidade Federal Fluminense (UFF), Niterói/RJ, 2018.

CHARAUDEAU, Patrick. Discurso das Mídias. São Paulo: Contexto, 2018.

Problemas de Análises das Mídias. In: MEDITSCH, Eduardo. Teorias do rádio: textos e contextos. Florianópolis: Insular, 2005. p 223-230.

FERREIRA, Marinéia. Comunicação comunitária. Disponível em:

https://www.politize.com.br/comunicacao-comunitaria/. Acesso em: 30 abr. 2020.

FIGUERÊDO, Maria Aparecida de. Gênese e (re)produção do espaço da Baixada Fluminense. Revista Geo-Paisagem (online), ano 3, n. 5, jan./jun. 2004. Disponível em: http://www.feth.ggf.br/baixada.htm. Acesso em: 24 abr. 2020.

IAZETTA, Fernando. A imagem que se ouve. Diálogos Transdisciplinares: Arte e Pesquisa. Disponível em: http://www3.eca.usp.br/sites/default/files/form/biblioteca/acervo/producaoacademica/002791473.pdf. Acesso em: 30 ago. 2020.

KISCHINHEVSKY, Marcelo. Rádios e mídias sociais: mediações e interações radiofônicas em plataformas digitais de comunicação. Rio de Janeiro: Mauad X, 2016. 152 p.

LOPEZ, Debora Cristina. Radiojornalismo hipermidiático: tendências e perspectivas do jornalismo de rádio all news brasileiro em um contexto de convergência tecnológica. Covilhã, Portugal: LabCom, 2010. Disponível em: http://labcom.ubi.pt/ficheiros/20110415debora_lopez_radiojornalismo.pdf. Acesso em: 17 ago. 2020.

LÓPEZ VIGIL, José Ignacio. Manual urgente para radialistas apaixonados. São Paulo: Paulinas, 2003, 518 p.

PERUZZO, Cicilia M. Krohling. Participação nas rádios comunitárias no Brasil. Anais do XXI Congresso Brasileiro de Ciências da Comunicação, GT Cultura e Comunicação Popular, Recife, set. 1998. Disponível em: http://www.bocc.ubi.pt/pag/peruzzo-cicilia-radio-comunitariabr.pdf. Acesso em: 8 maio 2020.

SALOMÃO, Mozahir. Jornalismo radiofônico e vinculação social. São Paulo: AnnaBlume, 2003. 144 p. 
SANTOS, Rodrigo Dolandeli dos. Rádio Novos Rumos: 17 anos de luta. Fenaj, 28 jan. 2008. Disponível em: https://fenaj.org.br/radio-novos-rumos-17-anos-de-luta/. Acesso em: 23 abr. 2020.

SILVA, Ana Carolina Ferreira Rodrigues da. Vozes da Baixada: um estudo sobre rádio comunitária em Queimados e São João de Meriti. 101 p. Dissertação de mestrado. Programa de Pós-Graduação em Sociologia, PUC-Rio, 2007.

TORRES, Bruno Araújo. O movimento de democratização do rádio no panorama latinoamericano. Anais do Encontro Nacional de História da Mídia, Mídia Alternativa e Alternativas Midiáticas, Fortaleza, Ceará, ago. 2009. Disponível em: http://www.ufrgs.br/alcar/encontros-nacionais-1/encontros-nacionais/7o-encontro-20091/O\%20movimento $\% 20 \mathrm{de} \% 20 \mathrm{democratizacao} \% 20 \mathrm{do} \% 20$ radio\%20no\%20panorama.pdf. Acesso em: 4 set. 2020.

VIANNA, Graziela Valadares Gomes de Mello. Elementos sonoros da linguagem radiofônica: a sugestão de sentido ao ouvinte-modelo. Galáxia, São Paulo, v. 14, n. 27, jan./jun. 2014. Disponível em:

https://www.scielo.br/scielo.php?pid=S198225532014000100019\&script=sci_arttext\&tlng=pt. Acesso em: 17 ago. 2020 